NABIR Final Report ID \# 0000490 Register \# ER62278 DE-FC02-96ER62278 (NABIR Assessment Element, Expanded Rapid, Comprehensive, Lipid Biomarker Analysis for Subsurface, Community Composition and Nutritional/Physiological Status as Monitors of Remediation and Detoxification Effectiveness (10/01/99-9/30/04).

\title{
Objectives:
}

The primary objective was to develop, update, and expand quantitative methods of assaying microbial communities in situ. The secondary objective was to provide comprehensive lipid biomarker analysis for NABIR collaborators to enhance the understanding of microbial bioprocesses and how those bioprocesses may be manipulated to achieve a desired response, as in the immobilization of metals.

Progress with lipid methods development

\section{Respiratory Quinones}

The reduction of uranium must be preceded by reduction of the high-potential electron acceptors $\mathrm{O}_{2}$ and $\mathrm{NO}_{3}{ }^{-}$. Reduced organic compounds are added to poise the redox potential and promote reduction of $U(V I)$ to insoluble $U(I V)$ compounds. At the FRC and UMTRA sites, organic compounds such as acetate, ethanol, and glucose were used as electron donors to create the necessary anaerobic conditions within the portion of the saturated zone surrounding treatment wells. All respiration, including respiration of $U$, is mediated by quinones. When the terminal electron acceptor is oxygen or nitrate, either ubiquinones or menaquinones may be used. Under anaerobic respiration (for example iron, sulfate, or U) menaquinones are used. Fermentation, which predominates under extremely anaerobic conditions, does not require quinones. Therefore, the ratio of menaquinones to total quinones is proportional to the ratio of anaerobic respiration to total respiration, and the ratio of total quinones to PLFA is proportional to the ratio of respiration to (respiration + fermentation). Respiratory quinones are found in concentrations at least 200 times less than the PLFA or about 0.5 micro mole/g dry weight, but can be quantified at high specificity and sensitivity with LC/MS/MS. CBA's development of sensitive methods utilizing LC/MS/MS for respiratory quinones have enabled detection in environmental samples (Lytle et al, 2001a, 2001b). Determination of the isoprenologues of the respiratory quinones also provides insight into the community composition and in quinone profiling. This work has been published (Lytle et al., 2000a, Geyer et al., 2004).

\section{Diglyceride Fatty Acids}

Recently CBA has developed for routine use (via LC/MS/MS) the ability for specific analysis of diglyceride fatty acids (Lytle et al, 2000b). These compounds are polar lipid derived moieties that are breakdown products of previously intact microbial cell membranes. When the cell dies it releases endogenous lipases that cleave the phosphate head group from the glycerol backbone. The diglycerides can be selectively extracted and derivatized at a highly specific level and quantified by LC/MS/MS. By analyzing the fatty acid chain moities of the diglycerides we can gain insight into community succession and competition quantitatively at the cellular level. The information provided by diglycerides may also be used to monitor the turnover of cellular biomass in systems under study. This may be particularly useful in sediments where only a portion of the microbial community is active. 
Recent work with Joel Kostka has revealed a potential biomarker for acid-tolerant Grampositive dissimilatory iron-reducing bacteria. This laboratory analyzed the fatty acid profiles of over fifty of these organisms, and the vast majority of them contained DMAs. DMAs are found in Clostridia and close relatives as well as some Gram-negative bacteria. This suggests that DMA's may be used to quantitatively monitor this class of microbes in situ. In work at the FRC, we have detected an increase of DMA's in low pH areas (Peacock et al, 2003) and after acetate injection at the Old Rifle UMTRA site (Peacock et al, 2002).

Analysis of ${ }^{13} \mathrm{C}$ Lipids

Lipid biomarker analysis of samples spiked with stable isotopes is a new approach in microbial ecology. Natural abundance isotope ratios have been used in a number of applications to study organic matter utilization in complex systems such as soil and groundwater. ${ }^{13} \mathrm{C}$ - labeled substrates are incorporated into lipid and DNA biomarkers, providing direct in situ identification of microbes involved in specific processes and goes to the heart of microbial activity (Chang 2005). The combination of the new lipid techniques coupled with stable isotope analysis will enable investigation into microbial community dynamics heretofore not possible.

High throughput 165 rDNA analysis by DGGE Community composition is specifically assessed by isolating DNA then amplifying specific portions of the genome with PCR. This is done by proper selection of primers and in environmental applications is usually focused on the genes for ribosomal RNA (rDNA) (Steven et al, 1999), although genes for specific functions can be utilized (Ivanova et al, 2000). The PCR amplicons are separated by denaturing gel gradient electrophoresis (DGGE). The prominent bands are excised, eluted, and sequenced. The sequences are then compared to a database and phylogenetic matching gives indications of the community diversity and dominant members (Chang et al, 2001).

Analysis of reduced metals at the micron scale

Endogenous U(IV) and associated mineralogy can now be measured by electron microscopy dark-field back scattered electron, scanning transmission electron microscopy (BE-STEM). However, in many instances, concentrations of U(IV) on surfaces are extremely low, requiring the low-level $U$ detection and imaging available at APS (PNC-CAT). Initial analysis at PNC-CAT of both sediment and samples of amorphous FeS sludge from the bottom of injection gallery wells from the Old Rifle Biostimulation Experiment show reduced $U$ localized in micron-sized clusters, providing direct evidence for microbial reduction of U(VI) to U(IV) with acetate addition (Long, personal communication, reported initially at the 2003 NABIR PI meeting). The next step in this development is the linkage of this type of evidence to samples where metabolic processes are also known from ${ }^{13} \mathrm{C}$-acetate labeling.

Sampling Devices

\section{Solid phase samplers}

Timely access to solid phase (sediment) samples can be limited by mobilization, drilling costs and possible concerns for existing well field integrity (Peacock et al., 2004). However it can be critical in the course of a biostimulation experiment to monitor changes at multiple time points. Groundwater grab samples provide a snapshot in time but are dependent on the hydrology of the day (i.e. recent rain or drought events). As such there is an associated noise factor in the data produced from such samples. Most 
bacteria exist attached to surfaces, and sampling groundwater artificially excludes these communities. Additionally, in some sediment environments recovery of DNA is limited by humics, clays or other materials. In order to compensate for the chaotic signal from aqueous samples and the impediments of direct sediment sampling we developed a solid phase sampler that is deployed down well and acts as a sensitive recorder of biostimulation in the subsurface. Assessment of the extant in-situ microbial community in subsurface environments is most effectively accomplished if the solid phase samplers can be readily colonized by the resident microbiota. We have established that solventresistant autoclavable polyfluorylalkoxy (PFA) 1.5" long, 5/8" diameter perforated tubes stuffed with glass wool (incinerated to remove organic carbon) or filled with Bio-Sep beads, are readily colonized in FRC groundwaters (Peacock, et al, 2004). Bio-Sep beads [described in U. S. patent $5,486,292$ ] are $2-3 \mathrm{~mm}$ spherical beads consisting of $25 \%(w / w)$ aramid polymer (Nomex) and $75 \%(w / w)$ powdered activated carbon (PAC). The bulk density is about $0.16 \mathrm{~g} / \mathrm{cm}^{3}$ with a porosity of $74 \%$, and an adsorptive capacity greater than $600 \mathrm{~m}^{2} / \mathrm{g}$. The beads are surrounded by an ultrafiltration-like membrane with a median pore diameter of 1.9 microns and with some large macropores $>20$ microns. Beads can be purged of organic carbon by incubation at $350 \mathrm{C}$ for at least 5 hours. A variety of solid phase samplers have been tested. Initial results indicate both the great utility of these devices in tracking changes in the microbial community, and their limitation due to differences in the well bore environment compared to the surrounding in situ sediment. For example, the well bore concentrations of oxidized $\mathrm{Fe}$ are typically low due the sparingly soluble nature of Iron III species. It is therefore likely that sulfate reduction can dominate in the well bore before sulfate reduction dominates in sediments. We propose to address this issue by providing similar levels of bioavailable oxidized Fe and other electron donor/acceptor combinations in solid phase samplers.

Provision of comprehensive biomarker analysis to collaborating NABIR investigators

Oak Ridge FRC Push-Pull

Sterile solid phase samplers loaded with glass wool or Bio-Sep biocatalyst beads were suspended down well to monitor subsurface microbial community dynamics during $U$ and Tc bioreduction tests conducted at the Oak Ridge Field Research Center. Diverse microbial biofilms colonized these surfaces during the six-week deployment. DNA and lipid biomarkers were extracted and recovered without complications that commonly plague sediment samples such as clay or humics. Changes in viable biomass, community composition, metabolic status and respiratory state were affected by substratum composition, addition of electron donors, and the alteration in groundwater $\mathrm{pH}$. The solid phase samplers provided a readily recoverable integrated microbial community that was serially monitored. This is in contrast to grab samples from the groundwater or the destructive one-time sampling of subsurface sediments each with well-documented heterogeneities in composition and activities. Compared to glass wool Bio-Sep beads induced biofilms that were 2 to13 times greater in viable biomass, however the community was less metabolically active (higher cyclopropane/monoenoic phospholipid fatty acid (PLFA) ratios) and had a lower aerobic respiratory state (lower total respiratory quinone/PLFA ratio and ubiqunone/menaquinone ratio). The biofilms in the treated wells were anaerobic as characterized by plasmalogen phospholipids and quinones. Partial 165 rDNA sequences identified Geobacter and nitrate reducing organisms induced by acetate, ethanol, or glucose additions. Although microbial community composition in the groundwater or adjacent sediments may differ from those formed on down-well solid phase samplers, the metabolic activity responses of the sampler biofilms to modifications in groundwater geochemistry parallel those of the 
adjacent sediments but maintain their integrative sampling and ease of recovery and analysis (Istok et al., 2004).

\section{UMTRA Old Rifle Biostimulation}

The Old Rifle Uranium Mill Tailings Remedial Action (UMTRA) site is a former ore-processing facility located approximately 0.3 mile east of the city of Rifle in Garfield County, $\mathrm{CO}$. The site is situated on a relatively low-lying alluvial terrace created by a flood-plain meander of the Colorado River. Uranium is the most prevalent site-related contaminant occurring in the alluvial ground water. Concentrations up to $0.35 \mathrm{mg} / \mathrm{L}$ present beneath the site exceed the UMTRA maximum contaminant level of $0.044 \mathrm{mg} / \mathrm{L}$, but steadily decrease to background levels near the downgradient edge of the site. During the first month of acetate addition in situ, $\mathrm{U}(\mathrm{VI})$ in groundwater decreased by more than $70 \%$. During the last 2 months of the experiment, the rate of $U(\mathrm{VI})$ reduction decreased, allowing $\mathrm{U}(\mathrm{VI})$ concentrations in groundwater in the treatment zone to increase (Well M-03, samples collected on 8/21/02 and 9/19/02). Background (control) samples (Well B-02) showed little change during the same time period. Other data indicate that $\mathrm{Fe}$ and $\mathrm{U}$ reduction dominated during the first 1.5 months of the experiment followed by sulfate reduction after bio-available oxidized $\mathrm{Fe}$ in the subsurface was consumed. The decreased rate of $U(V I)$ reduction in the latter half of the experiment is thus explained by the onset of sulfate reduction dominated by acetate oxidizing sulfate reducers, typically not effective at reducing $\mathrm{U}(\mathrm{VI})$.

The addition of acetate to the groundwater increased the microbial biomass on solid phase samplers by an order of magnitude within twenty-four feet of the injection gallery. By forty-eight feet downgradient, the microbial biomass returned to background levels. The starvation index (cyclopropyl to monounsaturate precursor ratio) was highest in the background and forty-eight feet downgradient of the treatment area, showing the biostimulation of the microbes in the immediate zone of effect. Analysis of 16S rDNA showed a diverse microbial community that included sulfate and metal reducers. Geobacter sp. (a known U reducer) was detected in the treatment area 12 feet from the injection gallery. Injection of the highly bioavailable acetate increased viable microbial biomass and decreased the starvation biomarker at both the shallow and deep wells immediately downgradient from the point of injection. Acetate addition created anaerobic conditions and stimulated the activity of $\mathrm{Fe}$ and $\mathrm{U}$ reducers resulting in reduction of soluble $U(V I)$ to insoluble $U(I V)$. The microbial community change associated with the acetate addition was readily detected by DNA and lipid biomarkers extracted from the traps. Specific rDNA analysis identified known $U$ and sulfate reducers whose quantitative proportions were reflected in the lipid biomarkers. The response of the biofilm communities in the BioSep beads to the acetate addition indicated that bioimmobilization could be induced and its perpetuation monitored. (Anderson et al., 2005).

In situ microcosm experiment using ${ }^{13} \mathrm{C}$ Benzene and Toluene Bio Sep beads loaded with ${ }^{13} \mathrm{C}$-labeled benzene and toluene (approx. $45 \mathrm{mg} / 50$ beads were exposed in-situ in a highly BTEX contaminated aquifer. There was essentially no exchange of label with the surrounding environment as indicated by gas chromatography/isotope ratio mass spectrometry (GC/IRMS). The isotopic signature of the contamination plume in the aquifer was ${ }^{13} \mathrm{C}-25$ atom\%. The isotopic signature of ${ }^{13} \mathrm{C}$-U-benzene and ${ }^{13} \mathrm{C}$-1-toluene utilized in the Bio Sep beads remained at 98 atom\% and 14 atom\%, respectively after 4 weeks. In the 4 week exposure more than $80 \%$ of the xenobiotics in the traps were degraded. The ${ }^{13} \mathrm{C}$-label could be detected in bacterial PLFA recovered from the Bio Sep beads and showed (up to delta $+13,000{ }^{13} \mathrm{C}$, which 
establishes the involvement of the bacteria in the biodegradation processes. PLFA recovered from unbaited control Bio Sep beads showed the natural ${ }^{13} \mathrm{C}$ abundance of around delta- $30{ }^{13} \mathrm{C}$. Bio Sep beads have a high affinity for organic compounds which serve as substrates for bacteria as indicated by the incorporation of ${ }^{13} \mathrm{C}$ into PLFA in the baited beads. There was preferential utilization of the ${ }^{13} \mathrm{C}$-labeled benzene and toluene in the baited beads. The unchanged isotopic ratio in the ${ }^{13} \mathrm{C}$-benzene and ${ }^{13} \mathrm{C}$-toluene solid phase samplers establishes that an exchange with the aquifer BTEX contamination by diffusion is very limited (not measureable) and the ${ }^{13} \mathrm{C}$-labeled baited material does not leak in the 4 week exposure. This exposure was sufficient for generation of a biofilm that incorporated ${ }^{13} \mathrm{C}$-into bacterial PLFA (Geyer et al., 2005).

Janet Chang of our laboratory has developed methods involving incubation of Bio Sep beads containing ${ }^{13} \mathrm{C}$ acetate in microcosms then isolating the DNA and subjecting the isolated DNA to density gradient centrifugation (Chang, 2005). She has been able to recover the ${ }^{13} \mathrm{C}$ labeled DNA and from the gradient then amplify with PCR to show that a subset of the microbial community was metabolically active. This work will form her PhD thesis. The three case studies indicate the technology of multi-compartment (MLS technology) sampling including solid phase samplers and newly expanded analyses of lipid and rDNA biomarkers, together with the effective baiting with ${ }^{13} \mathrm{C}$ labeled substrates and local incorporation of ${ }^{13} \mathrm{C}$ into biomarkers are an effective fieldtested monitoring system. This system can now be developed for validation as a costeffective means to determine if bio-immobilization can work and provide a monitoring system to assess post-remediation performance.

Support of Graduate Students and Post-Doctoral Fellows 1999-2004. In this program 5 graduate students were supported and 2 Ph.D. degrees awarded. Five Post Doctoral Fellows were supported by this project.

Peer-reviewed papers supported by DE-FC02-96ER62278 P.I., D.C. White 19992004. In this period CBA produced in one patent disclosure, 42-peer reviewed publications, $1 \mathrm{PhD}$ thesis, and 62 presentations with abstracts (not listed), 14 of which were international and there are currently 2 papers in press:

Anderson, R. T., H. A. Vrionis, I. Ortiz-Bernad, C.T. Resch, P. E. Long, R. Dayvault, K. Karp, S. Marutzky, D. R.Metzler, A. D. Peacock, D. C. White, M. Lowe, and D. R. Lovley. 2003. Stimulating the In Situ Activity of Geobacter Species to Remove Uranium from the Groundwater of a Uranium-Contaminated Aquifer. Appl. Env. Microbiol. 69 : 5884-5891.

Balkwill, D., J. Chen, M. DeFlaun, F. Dobbs, H. Dong, J. Fredrickson, M. Fuller, M. Green, T. Ginn, W. Holden, S. Hubbard, W. Johnson, P. Long, B. Mailloux, E. Majer, M. McInerney, C. Murray, T. Onstott, T. Phelps, T., D Swift, D. C. White, and F. Wobber. 2001. Breakthroughs in field-scale bacterial transport. Eos Transactions. 82: 41, 423425.

Buggemann J, J. R. Stephen, Y-J. Chang, S. J. Macnaughton, G. A. Kowalchuk, E. Kline, and D. C. White. 2000. Competitive PCR-DGGE analysis of bacterial mixtures: an internal standard and an appraisal of template enumeration accuracy. J. Microbiol. Methods 40: 111-123. 
Chang, Y-J. A. Peacock, P. E. Long, J. R. Stephen, J. P. McKinley, S. J. Macnaughton, A. K. M. Anwar Hussain, A. M. Saxton, and D. C. White. 2001. Diversity and Characterization of Sulfate-Reducing Bacteria in Groundwater at a Uranium Mill Tailings Site. Appl. Environ. Microbiol. 67: 3149-3160.

Chang, Y-J. 2005. In situ biostimulation of Uranium reducing microorganisms at old Rifle UMTRA site. PhD. Thesis, Department of Microbiology, University of Tennessee, Knoxville.

Crocker,et al., 2000. Phylogenetic and physiological diversity of Arthrobacter strains isolated from unconsolidated subsurface sediments. Microbiology 146: 12961310

Chun, S, R. Geyer, J. Lee, and D.C. White. 2005. Comparison of three extraction methods for $17 \beta$-estradiol in sand, clay, and organic-rich soils. J. Environ. Sci. Health. Series B 40: 731-740.

Geyer et al. 2004. Atmospheric Pressure Chemical lonization and Atmospheric Pressure Photoionization for Simultaneous Mass Spectrometric Analysis of Microbial Respiratory Ubiquinones and Menaquinones. J. Mass Spect. 39: 922-929.

Geyer . Geyer, R., Peacock, A. D., Richnow, H.-H., White, D.C., Sublette, K.L., Miltner, A., and Kästner, M. 2005. Monitoring of microbial activity using in situ microcosms 'Bug Traps' loaded with ${ }^{13}$ C-labeled benzene and toluene. Env. Sci. Technol. 39: 4983-4989.

Geyer, R., A. D. Peacock, D. C. White, C. Lytle, G. J. Van Berkel. 2004. Atmospheric Pressure Chemical Ionization and Atmospheric Pressure Photoionization for Simultaneous Mass Spectrometric Analysis of Microbial Respiratory Ubiquinones and Menaquinones. J. Mass Spect. 39: 922-929.

Gu, B., D.B. Watson, L. Wu, D.H. Phillips, D.C. White, and J.Z. Zhou. 2002. Diversity and Characterization of Sulfate-Reducing Bacteria in Groundwater at a Uranium Mill Tailings Site. Environ. Monit. Assess. 77(3):293-309.

Hedrick, D. B., A. Peacock, J. R. Stephen, S. J. Macnaughton, J. Bruggemann and D. C. White. 2000. Measuring soil microbial community diversity using polar lipid fatty acid and denaturing gradient gel electrophoresis data. J. Microbial. Methods 41: 235-248.

Istok, J.D, J.M. Senko, L. R. Krumholz, D. Watson, M.A. Bogle, A. Peacock, Y-J. Chang, and D.C. White. 2004. In Situ Bio-Reduction of Technetium and Uranium in a Nitrate-Contaminated Aquifer. Environ. Sci. Techn. 38 (2): 468-475.

Ivanova, I A., J. R. Stephen, Y-J. Chang, , J. Bruggemann, P. E. Long, J. P. McKinley, G. A. Kowalchuk, D. C. White, and S. J. Macnaughton. 2000. A survey of $16 S$ rRNA and amoA genes related to autotrophic ammonia-oxidizing bacteria of the $\beta$ subdivision of the class proteobacteria in contaminated groundwater. Canad $\mathrm{J}$. Microbiol. 46: 1012-1020.

Laskin A. L. and D. C. White 1999. Preface to special issue on Sphingomonas. J. Indust. Microbiol. 23: 231. 
Leung, K. T., Y-J. Chang, Y-D. Gan, A. Peacock, S. J. Macnaughton, J. R. Stephen, R. S. Burkhalter, C. A. Flemming and D. C. White. 1999. Detection of Sphingomonas spp. in soil by PCR and sphingolipid biomarker analysis. J. Industrial Microbiology. 23: 252-260.

Lytle, C.A., Y-D. M. Gan, and D. C. White 2000a. Electrospray lonization/Mass Spectrometry Compatible Reversed-Phase Separation of Phospholipids: Piperidine as a Post Column Modifier for Negative Ion Detection. J. Microbial. Methods 41: 227-234.

Lytle, C.A., G. J. Van Berkel, Y-D. M. Gan, and D. C. White 2000b. A Rapid Method for the Accurate Assessment of Diglycerides in Environmental Matrices. American Society for Mass Spectrometry Meeting, Abstract 1408, Long Beach, CA, June $11-15$

Lytle, C.A., Y-D. M. Gan, K. Salone, and D. C. White 2001a. Sensitive Characterization of Microbial Ubiquinones from Biofilms by Electrospray/Mass Spectrometry Environ. Microbiol. 3 (4): 265-272.

Lytle, C.A., M. E. Fuller, Y-D. M. Gan, A. Peacock, M. F. DeFlaun, T. C. Onstott and D. C. White. 2001b. Utility of High Performance Liquid

Chromatography/Electrospray /Mass Spectrometry of Polar Lipids in a Specific Per $-{ }^{13} \mathrm{C}$ Labeled Gram-negative bacteria DA001 as a tracer for acceleration of bioremediation in the subsurface. J. Microbial. Methods. 44: 271-281.

Macnaughton, S. J., J. R. Stephens, A. D. Venosa., G. A. Davis, Y-J. Chang, and D. C. White. 1999. Microbial population changes during bioremediation of an experimental oil spill. Appl. Environ. Micobiol. 65: 3566-3574.

Musslewhite, C. L.., M. J. Mclnerney, H. Dong, T. C. Onstott, M. Green-Blum, D. Swift, S. J. Macnaughton, D. C. White, C. Murray, and Y-J. Chien. 2003. The factors controlling microbial distribution and activity in the shallow subsurface. Geomicrobiology 20 (3): 245-261.

Onstott, T.C., D.P. Moser, S.M. Pfiffner, J.K. Fredrickson, F.J. Brockman, T.J. Phelps, D.C. White, A. Peacock, D. Balkwill, H. Hoover, L.R. Krumholtz, M. Borscik, T. L. Kief, and R. Wilson.2003. Indigenous and contaminant microbes in ultradeep mines. Environmental Microbiology.5(11):1168-1191.

Peacock, A.D., Y-J. Chang, J. D. Istok, L. Krumholz, R. Geyer, B. Kinsall, D. B. Watson, K. L Sublette, and D. C. White. 2004. Utilization of Microbial Biofilms as Monitors of Bioremediation. Microbial Ecology 47 (3):284-292.

Pfiffner et al. (2001) Microbial heterogeneity implications for bioremediation. In (In Situ and On-Site Bioremediation, B. Allenman and A. Leeson Eds.) 20016 (4): 73-80.

Phillips, R.W., J. Wiegel, C. J. Berry, C. Fliermans, A. Peacock, D. White, and L. J. Shimkets. 2002. Kineococcus radiotolerans sp. nov.: a radiation-resistant, grampositive bacterium. Int. J. Systematic. Bacteriol. 52: 933-938. 
Pinkart, H. C., D. B. Ringelberg, Y. M. Piceno, S. J. Macnaughton, and D. C.White. 2002. Biochemical approaches to biomass measurements and community structure analysis. In Manual of Environmental Microbiology, $2^{\text {nd }}$ Edition (D. E. Stahl, C. H. Hurst, G. R. Knudsen, M. J. McInerney, L. D. Stetzenbach, and M. V. Walter, eds.) American Society for Microbiology Press, Washington, DC. pp. 101-113.

Singleton D. R., M. A. Furlong, A. D. Peacock, D. C. White, D. C. Coleman and W. B. Whitman. 2003. Solirubrobacter pauli gen nov., sp., a mesophilic bacterium within the Rubrobacterodae related to common soil clones. Int. J. Syst. And Evol. Microbiol. 53: 485-490.

Stephen, J. R., Y-J. Chang, Y. D. Gan, A. Peacock, S. M. Pfiffner, M. J. Barcelona, S. M. D. C. White, and S. J. Macnaughton. 1999. Microbial Characterization of JP-4 fuel contaminated-site using a combined lipid biomarker/PCR-DGGE based approach. Environmental Microbiology. 1: 231-241.

Ward, D. C. and D. C. White 2002. The new 'Omics era. Current Opinion in Biotechnology 13: 11-13.

White, D. C. 1999. Environmental biotechnology: Better living through biochemistry. Current Trends in Biotechnology 10: 217-219.

. White, D. C., C. A. Lytle, Y-D. M. Gan, Y. M. Piceno, M. H. Wimpee, A. Peacock and C. A. Smith 2002. Flash Detection/identification of Pathogens, Bacterial Spores and Bioterrorism Agents Biomarkers from Clinical and Environmental Matrices. J. Microbial Methods 48: 139-147.

White, D.C., A. Peacock, R. Geyer, Y-J. Chang, Y-D. M. Gan, and C. A. Lytle 2003. Rapid Detection/Identification Of Microbes, Bacterial Spores, Microbial Communities, and Metabolic Activities In Environmental Matrices. In The Utilization of Bioremediation to Reduce Soil Contamination: Problems And Solutions (V. Sasek, J. A. Glasser, and P. Baveye, eds.), Kluwer Academic Publishers, Norwell, MA, pp. 1-19.

White, D. C, Y-J. Chang, A. D. Peacock, P. E. Long, J. P. McKinley, A. K. M. Anwar Hussain, A. M. Saxton, J. S. Almeida, S. J. Macnaughton, J. R. Stephen, T. L. Marsh, D. Long, and G. Icopini, 2001. Assessment of the impact of $\mathrm{Cr}$ (III) and U(VI) contamination on soil and sediment microbial community composition. Proceedings of the $6^{\text {th }}$ International Conference on the Biogeochemistry of Trace Elements, Guelph, Ontario, July 29-Aguust $2^{\text {nd }}$ p. 336.

Zhang, C. L., Y. Li, J. D. Wall, L. Larsen, R. Sassen, Y. Huang, Y. Wang, A. Peacock, D. C. White, J. Horita, D.R. Cole. 2001. Lipid and carbon isotopic evidence of methane-oxidizing and sulfate-reducing bacteria in association with gas hydrates from the Gulf of Mexico. Geology 30: 239-242.

Zhang, C. I., Q. Ye, D. Goetz, A-L. Reysenbach, A. Peacock, D. C. White, J. Horita, D. R. Cole, J. Fang, L. Pratt, J. Fang, and Y. Huang. 2002. Carbon isotopic fractionations associated with thermophilic bacteria Thermotoga maritima, and Persephonella marina. Environmental Microbiology 4: 58-64. 
Patent disclosure Feb. 17, 2003 on behalf D. C. White, A. D. Peacock, \& G. A. Davis, for the University of Tennessee Research Foundation and Microbial Insights, Inc., Rockford, TN "Use of stable isotope enriched solid phase samplers for defining specific microbial Activities". 